\title{
Pembuatan Keputusan Dalam Proses Manajemen Dan Aspek Manajemen
}

\author{
Maidiana1, Saima Putrini R. Harahap $^{2}$
}

${ }^{1}$ Universitas Islam Negeri Sumatera Utara Medan

${ }^{2}$ Politeknik Negeri Ketapang

Corresponding Author : Sihombingmaidiana19@gmail.com

\begin{tabular}{ll}
\hline & \multicolumn{1}{c}{ ABSTRACT } \\
\cline { 2 - 3 } & Proses pembuatan keputusan seorang manajer yaitu: 1) Pemahaman dan \\
perumusan masalah, 2) Pengumpulan dan analisa data yang relevan. 3) \\
Pengembangan alternatif-alternatif. 4) Evaluasi alternatif-alternatif. 5) \\
Pemilihan alternatif terbaik. 6) Implementasi keputusan, 7) Evaluasi \\
hasil-hasil keputusan. Proses pengambilan keputusan memiliki berapa \\
tahapan : Tahap 1. Pemahaman dan Pemecahan Masalah. Tahap 2 \\
Pengumpulan dan Analisis Data yang akurat. Tahap 3 Pegembangan \\
Alternatif-Alternatif. Tahap 4 Evaluasi Alternatif-Alternatif. Tahap 5 \\
Pemilihan Alternatif Terbaik. Tahap 6 Implementasi Keputusan. Tahap 7 \\
Evaluasi Hasil-Hasil. Keputusan. Analisis SWOT adalah indentifikasi \\
secara sistematis untuk merumuskan strategi perusahaan, termasuk \\
strategi pemasaran. Analisis ini didasarkan logika yang dapat \\
memaksimalkan Strengths (Kekuatan), Opportunities (Peluang), Weaknesses \\
(Kelemahan), dan Treats (Ancaman). Proses pengambilan keputusan \\
strategis selalu berkaitan dengan pengembangan misi, tujuan, strategi, \\
dan kebijakan organisasi. Tim pemecahan masalah dan pengambilan \\
keputusan merupakan jantung kegiatan keputusan. Tempat pengendali \\
internal merupakan persepsi orang -orang mengenai kemapuan mereka \\
untuk melakukan tindakan khusus, seperti memecahkan masalah. \\
Penggunaan metode pemecahan masalah yang efektif cenderung dapat \\
menjamin bahwa akar permasalahan sudah diidentifikasi, ditentukan, \\
dianalisis, dan diukur. Dengan menggunakan masukan ganda dan \\
metode pemecahan masalah yang menjamun penemuan akar \\
permasalahan, tim bisa menjajaki permasalahan kenbali menuju ke sebab \\
awal masalah itu. Dengan mengidentifikasi akar permasalahan, dapat \\
menggalakkan penyeleksian solusi yang berhadapan langsung dengan \\
pemecahan daripada gejala-gejala saja.
\end{tabular}

\section{PENDAHULUAN}

Setiap organisasi, baik dalam skala besar maupun kecil, terdapat terjadi perubahan-perubahan kondisi yang dipengaruhi oleh faktor-faktor lingkungan eksternal dan internal organisasi. Dalam menghadapi perkembangan dan perubahan yang terjadi maka diperlukan pengambilan keputusan yang cepat dan tepat. Proses pengambilan keputusan yang cepat dan tepat dilakukan agar roda organisasi beserta administrasi dapat berjalan terus dengan lancar. 
Ability : Journal of Education and Social Analysis

Volume 2, Issue 3, Juli 2021

Page : 83-92

Pengambilan keputusan tersebut dilakukan oleh seorang manajer atau administrator. Kegiatan pembuatan keputusan meliputi pengindentifikasian masalah, pencarian alternatif penyelesaian masalah, evaluasi daripada alternatif-alternatif tersebut, dan pemilihan alternatif keputusan yang terbaik. Kemampuan seorang pimpinan dalam membuat keputusan dapat ditingkatkan apabila ia mengetahui dan menguasai teori dan teknik pembuatan keputusan. Dengan peningkatan kemampuan pimpinan dalam pembuatan keputusan maka diharapkan dapat meningkatkan kualitas keputusan yang dibuatnya, sehingga akan meningkatkan efisiensi dan efektivitas kerja organisasi.

Pembuatan keputusan diperlukan pada semua tahap kegiatan organisasi dan manajemen. Misalnya, dalam tahap perencanaan diperlukan banyak kegiatan pembuatan keputusan sepanjang proses perencanaan tersebut. Sedangkan dalam tahap pengawasan yang mencakup pemantauan, pemeriksaan, dan penilaian terhadap hasil pelaksanaan dilakukan untuk mengevalusai pelaksanaan dari pembuatan keputusan yang telah dilakukan. Hakikatnya kegiatan administrasi dalam suatu organisasi adalah pembuatan keputusan.

Kegiatan yang dilakukan tersebut mencakup seluruh proses pengambilan keputusan dari mulai identifikasi masalah sampai dengan evaluasi dari pengambilan keputusan yang melibatkan seluruh elemen-elemen dalam administrasi sebagai suatu sistem organisasi.

\section{METODE PENELITIAN}

Penelitian ini menggunakan studi kepustakaan (library research). Dalam memperoleh data penelitian, peneliti mengumpulkan, menganalisis, mengorganisasi, sumber dari artikel, buku, penelitian terdahulu tentang implementasi manajemen strategi dalam bidang pendidikan. Kemudian peneliti menyimpulkan dan menyajikan data-data manajemen strategi untuk peningkatan mutu pendidikan (Danandjaja, 2014; Sari \& Asmendri, 2020; Zed, 2014).

\section{HASIL DAN PEMBAHASAN}

Pembuatan keputusan adalah bagian kunci kegiatan manajer. Kegiatan ini memainkan peran penting, terutama bila manajer melaksanakan fungsi perencanaan. Perencanaan menyangkut keputusan-keputusan sangat penting dan jangka panjang yang dapat dibuat manajer.

Pembuatan keputusan (decision making) menggambarkan proses melalui bagaimana serangkaian kegiatan dipilih sebagai penyelesaian suatu masalah tertentu. Handoko (2000 : 129) mengatakan bahwa pengambilan keputusan merupakan hal yang sangat penting bagi individu maupun organisasi. Mengambil keputusan kadang-kadang mudah tetapi lebih sering sulit sekali.

\section{A. Aspek Pengambilan Keputusan}

Terdapat tiga aspek dalam pengambilan keputusan (Janis \& Mann, 1977), yaitu :Pertama, kemampuan mempertimbangkan beberapa pilihan, Individu tidak hanya 
Ability : Journal of Education and Social Analysis

Volume 2, Issue 3, Juli 2021

Page : 83-92

memikirkan manfaat terbesar yang akan didapatkan, tetapi juga berbagai macam pertimbangan dari pilihan yang dipilih maupun yang tidak dipilih. Kedua, kemampuan menghadapi tntangaan untuk mencapai situasi yang diinginkan. Berbagai tantangan yang kemungkinan akan dihadapi oleh individu dapat dilalui dengan baik. Berkenaan dengan ketidakpastian, sehingga pilihan yang telah dipilih tiak dapat diubah lagi. Ketiga, kemampuan untuk menerima resiko yang ada.

Sedangkan menurut faqih (2012) aspek-aspek pengambilan keputusan studi lanjut menurut Hasan antara lain :

1. Memahamai potensi diri. Memahami potensi diri dimaksudkan siswa memiliki kesanggupan untuk membentuk suatu gambaran tentang dirinya sendiri, tentang kelebihan, kekurangan, sifat-sifat, bakat dan minat yang ada dalam dirinya.

2. Memahami lingkungan. Memahami lingkungan dimaksudkan siswa memiliki kesanggupan untuk memahami dan menggambarkan keadaan lingkungannya baik lingkungan keluarga, lingkungan sekolah, dan lingkungan sekitar seingga menunjukkan suatu keadaan yang jelas.

3. Menemukan hambatan-hambatan dalam mengambil keputusan studi lanjut. Menemukan hambatan dalam mengambil keputusan berarti siswa sangup menemukan, mengidentifikasi, keadaan yang menghambatnya dalam mengambil keputusan.

4. Memutuskan pilihan berdasarkan alternatif yang ada. Memutuskan pilhan berdasarkan alternatif yang ada berarti siswa mampu memahami diri, memahami keadaa lingkungan, dan mampu menemukan hambatan dalam mengambil keputusan studi lanjut yang kemudian hal tersebut menjadi bahan pertimbangan dalam mengambil keputusan.

\section{B. Faktor-Faktor Pengambilan Keputusan}

Menurut Terry (1989) dalam blog Komunitas Diamond faktor-faktor yang harus diperhatikan dalam mengambil keputusan sebagai berikut:

1. Hal-hal yang berwujud maupun tidak berwujud, yang emosional maupun rasional perlu diperhitungkan dalam pengambilan keputusan;

2. Setiap keputusan nantinya harus dapat dijadikan bahan untuk mencapai tujuan organisasi;

3. Setiap keputusan janganlah berorientasi pada kepentingan pribadi, perhatikan kepentingan orang lain;

4. Jarang sekali ada 1 pilihan yang memuaskan;

5. Pengambilan keputusan merupakan tindakan mental. Dari tindakan mental ini kemudian harus diubah menjadi tindakan fisik;

6. Pengambilan keputusan yang efektif membutuhkan waktu yang cukup lama;

7. Diperlukan pengambilan keputusan yang praktis untuk mendapatkan hasil yang baik; 
Ability : Journal of Education and Social Analysis

Volume 2, Issue 3, Juli 2021

Page : 83-92

8. Setiap keputusan hendaknya dikembangkan, agar dapat diketahui apakah keputusan yang diambil itu betul; dan

9. Setiap keputusan itu merupakan tindakan permulaan dari serangkaian kegiatan berikutnya.

Selanjutnya, John D.Miller dalam Imam Murtono (2009) menjelaskan faktorfaktor yang berpengaruh dalam pengambilan keputusan adalah: jenis kelamin pria atau wanita, peranan pengambilan keputusan, dan keterbatasan kemampuan. Dalam pengambilan suatu keputusan individu dipengaruhi oleh tiga faktor utama yaitu nilai individu, kepribadian, dan kecenderungan dalam pengambilan risiko.

Selanjutnya Dalam Judul Skripsi Pengambilan Keputusan yang tepat yang disusun Sumaryanto Sarjana Universitas Negeri Yogyakarta, dalam pengambilan keputusan ada beberapa faktor yang mempengaruhi, antara lain:

1. Posisi kedudukan

2. Masalah

3. Situasi

4. Kondisi

5. Tujuan

\section{Prinsip Pengambilan Keputusan Dalam Islam}

Ada berapa prinsip dalam pengambilan keputusan yang penting dipertimbangkan untuk mengambil keputusan yaitu (1) Keputusan yang baik tidaklah harus disukai oleh semua oran; (2) Pendapat orang lain yang perlu dipertimbangkan, memang dibutuhkan dalam informasi, namun yang terpenting adalah bukan banyaknya informasi, melainkan bagaimana orang yang memberi pendapat memahami duduk permasalahan yang akan diselesaikan.; (3) Kebijakan efektif sangat bergantung bagaimana pengambil keputusan berpandangan adil dan memilki kemaslahatan bagi anggota organisasi dan bagi orang lain; (4) Keputusan tidak merugikan orang lain; (5) Keputusan yang baik bisa saja tidak harus langsung berdampak, terkadang membutuhkan waktu lama mewujudkannya; (6) Kesalahan dalam mengambil keputusan dikarenakan tidak semua keputusan yang di ambil benar.

Adapun dalam Islam dapat dipelajari beberapa prisnsip sebagai berikut. Dalam surah al-Baqarah :30 terdapat prinsip pengambilan keputusan individu ketika Allah memutuskan untuk menciptkan manusia, sementara malaikat mengatakan bahwa manusia akan membuat kerusakan. Selanjutnya dalam surah asy-Syuura' : 38 menyampaikan soal shalat dan pentingnya menyelesaikan masalah secara musyawarah.

Kemudian dalam Q.S. Ali Imran [3] :159 terdapat pesin pentingnya melakukan musyawarah untuk persoalan tertentu yang dapat diterapkan seorang manajer ketika mengambil keputusan. Dalam ayat ini terkandung makna bahwa : seorang pemimpin menghindari tutur kata yang kasat namun lebih menampakkan kelembutan; keputusan ditujukan untuk kemaslahatan bersama. 
Ability : Journal of Education and Social Analysis

Volume 2, Issue 3, Juli 2021

Page : 83-92

\section{Proses Pembuatan Keputusan}

Proses pembuatan keputusan rasional oleh manajer melewati beberapa tahapan, sebagai berikut:

1. Pemahaman dan perumusan masalah

Hal pertama yang harus dilakukan oleh manajer dalam pembuatan keputusan adalah memahami masalah yang sedang dihadapi, dan peka terhadap masalahmasalah. Setelah masalah telah dipahami dengan baik, selanjutnya menentukan bagian-bagian masalah yang harus dipecahkan. Para manajer dapat mempermudah identifikasi masalah dengan cara sistematik menguji hubungan sebab-akibat.

2. Pengumpulan dan analisa data yang relevan

Setelah manajer menentukan dan merumuskan masalah mereka harus mulai memutuskan langkah-langkah selanjutnya. Manajer pertama kali harus menentukan data-data apa yang dibutuhkan untuk membuat keputusan yang tepat, dan kemudian mendapatkan informasi tersebut.

3. Pengembangan alternatif-alternatif

Pengembangan sejumlah alternatif memungkinkan manajer menolak kecendrungan untuk membuat keputusan terlalu cepat dan membuat lebih mungkin pencapaian keputusan yang efektif.

4. Evaluasi alternatif-alternatif

Setelah manajer mengembangkan alternatif-alternatif, mereka harus mengevaluasinya untuk menilai efektifitas setiap alternatif. Efektifitas dapat diukur dengan dua kriteria : apakah alternatif tersebut realistik bila dihubungkan dengan tujuan dan sumber daya organisasi/perusahaan, dan seberapa baik alternatif akan membantu pemecahan masalah.

5. Pemilihan alternatif terbaik

Tahap kelima pembuatan keputusan merupakan hasil evaluasi berbagai alternatif. Alternatif terpilih akan didasarkan pada jumlah informasi yang tesedia bagi manajer dan ketidak sempurnaan kebijakan manajer.

6. Implementasi keputusan

Setelah alternatif terbaik dipilih, para manajer harus membuat rencana-rencana untuk mengatasi berbagai persyaratan dan masalah yang mungkin dijumpai dalam penerapan keputusan. Implementasi keputusan menyangkut lebih dari sekedar pemberian perintah. Manajer harus menetapkan anggaran atau jadwal rencana kegiatan, mengadakan dan mengalokasikan sumber daya-sumber daya yang diperlukan, serta menugaskan tanggung jawab dan wewenang pelaksanaan tugas-tugas tertentu.

7. Evaluasi hasil-hasil keputusan

Implementasi keputusan harus dimonitor terus memnerus. Manajer harus mengevaluasi apakah implementasi dilakukan dengan lancar dan keputusan memberikan hasil-hasil yang diinginkan. 
Ability : Journal of Education and Social Analysis

Volume 2, Issue 3, Juli 2021

Page : 83-92

\section{E. Tahap Pengambilan Keputusan}

Menuru Freddy Rangkuti (2008) proses pengambilan keputusan memiliki berapa tahapan sebagai berikut :

\section{Tahap 1}

Pemahaman dan Pemecahan Masalah. Para manager kerap kali menghadapi kenyataan bahwa masalah yang didapat sebenarnya sulit selesaikan atau bahkan sering hanya menyimpulkan masalah, bukan penyebab awal. Para manager dapat menyimpulkan dalam mengidentifikasi masalah dengan beberapa cara. Pertama, manager secara teori dapat menguji hubungan sebab-akibat. Kedua manager dapat mencari penyimpangan atau perubahan dari yang normal dan secara teoritis.

\section{Tahap 2}

Pengumpulan dan Analisis Data yang akurat. Setelah manajer menemukan dan merumuskan untuk memcahkan masalah, manajer harus memutuskan langkahlangkah selanjutnya. Manajer pertama kali harus menentukan data-data apa yang dibutuhkan untuk membuat keputusan yang akurat akan mendapatkan informasi tersebu

\section{Tahap 3}

Pegembangan Alternatif-Alternatif. kebiasan untuk menerima alternatif keputusan pertama yang simpel sering mengesampingkan manager dari pencapaian penyelesaian yang terbaik untuk masalah manajer.Pengembangan sejumlah alternatif memungkinkan manajer menolak kehendak untuk membuat keputusan terlalu cepat dan melakukan keputusan yang benar. Manager harus memilih suatu pendapat yang cukup baik, walaupun bukan pendapat yang sempurna atau baik.

\section{Tahap 4}

Evaluasi Alternatif-Alternatif. Setelah manajer mengumpulkan sekumpulan alternatif, mansger harus mengevaluasi sekumpulan alternatif, manager harus mengevaluasi untuk menilai efektifitas pada setiap alternatif.

\section{Tahap 5}

Pemilihan Alternatif Terbaik. Pembuatan keputusan menggambarkan hasil evaluasi berbagai alternatif. Alternatif terpilih akan didasarkan pada jumlah informasi bagi manager dan ketidaksempurnaan kebijakan manajer.

\section{Tahap 6}

Implementasi Keputusan . Setelah alternatif terbaik telah dipilih, para manager harus membuat keputusan untuk melakukan berbagai permasalahan dan masalah yang mungkin akan terjadi dalam penggunaan keputusan. Dalam hal ini, manager perlu mengendalikan berbagai resiko dan ketidakpastian sebagai pengaruh dibuatnya suatu keputusan.

\section{Tahap 7}

Evaluasi Hasil-Hasil. Keputusan. Implementasi keputusan harus selalu di perhatikan Manajer harus dapat memecahkan masalah apakah implementasi dilakukan dengan baik dan keputusan memberikan hasil yang diinginka. 
Ability : Journal of Education and Social Analysis

Volume 2, Issue 3, Juli 2021

Page : 83-92

\section{F. Analisis Swot Sebagai Alat Formulasi Strategi}

Analisis SWOT adalah indentifikasi secara sistematis untuk merumuskan strategi perusahaan, termasuk strategi pemasaran. Analisis ini didasarkan logika yang dapat memaksimalkan Strengths (Kekuatan), Opportunities (Peluang), Weaknesses (Kelemahan), dan Treats (Ancaman). Proses pengambilan keputusan strategis selalu berkaitan dengan pengembangan misi, tujuan, strategi, dan kebijakan organisasi. Dengan demikian Strategic Planner ( Perencana Strategis ) harus menganalisis faktorfaktor strategis perusahaan (Kekuatan, Peluang, Kelemahan, dan Ancaman) dalam kondisi aktual saat ini. Hal ini disebut dengan analisis situasi. Model yang populer untuk analisis situasi adalah analisis SWOT, sehingga Perencana strategis dapat dengan mudah merencanakan strategi pemasaran.

Cara membuat analisis SWOT adalah dengan ditentukan oleh kombinasi faktor internal dan eksternal. Kedua faktor tersebut harus dipertimbangkan dalam analisis SWOT. Analisis SWOT membandingkan antara faktor internal dan eksternal.

\section{G. Tim Pemecahan Masalah}

Tim pemecahan masalah dan pengambilan keputusan merupakan jantung kegiatan keputusan. Tempat pengendali internal merupakan persepsi orang -orang mengenai kemapuan mereka untuk melakukan tindakan khusus, seperti memecahkan masalah. Tim pemecahan masalah mempromosikan kesempatan bagi individu dan tim-tim untuk meninjau persepsi dan keyakinan mereka mengenai apa yang benar. Tim kerja mengusahakan individu dan refleksi kelompok dan kritik mengenai posisi dan persepsi seseorang. Kesempatan ini menggalakkan peninjauan dan pembaruan pribadi. Penilaian diri mempromosikan keterbukaan pribadi dan kelompok, kemauan untuk berubah dan kemungkinan peningkatan kebaikan terus menerus.

Berikut disajikan tabel perbedaan pengambilan keputusan individu dan kelompok menurut Vroom dalam Muhammad Rifa'i (2020 :55)

\begin{tabular}{|c|c|}
\hline Untuk Masalah Individu & alah Kelompok \\
\hline $\begin{array}{l}\text { Anda meneyelesaikan masalah atau } \\
\text { membuat keputusan sendiri, } \\
\text { menggunakan informasi yang tersedia }\end{array}$ & $\begin{array}{l}\text { Anda meneyelesaikan masalah atau } \\
\text { membuat keputusan sendiri, } \\
\text { menggunakan informasi yang tersedia } \\
\text { disaat bersamaan }\end{array}$ \\
\hline $\begin{array}{l}\text { Anda mencari informasi yang } \\
\text { dibutuhkan ke bawahan, kemudian } \\
\text { memutuskan solusi untuk masalah Anda } \\
\text { sendiri. Anda tidak atau menceritakan } \\
\text { masalah ketika anda mencari informasi } \\
\text { dibawahan. Peran dimainkan oleh } \\
\text { bawahan Anda dalam memutuskan } \\
\text { informasi spesifik seperti apa yang and } \\
\text { pinta agar anda dapat memutuskan } \\
\text { sebuah masalah }\end{array}$ & $\begin{array}{l}\text { Semua yang anda cari dari bawahan } \\
\text { Anda, kemudian memutuskan solusi } \\
\text { untuk masalah anda. Anda mungkin } \\
\text { bisa atau tidak bisa menceritakan } \\
\text { bawahan apa masalahnya ke bawahan } \\
\text { apa masalah yang ada dalam upaya } \\
\text { mendapatkan informasi. Peranan ada di } \\
\text { tangan bawahan dalam membuat } \\
\text { keputusan secara jelas menyediakan } \\
\text { informasi spesifik yang anda pinta, }\end{array}$ \\
\hline
\end{tabular}




\begin{tabular}{|c|c|}
\hline & $\begin{array}{l}\text { daripada menggenerealisasi atau } \\
\text { mengevaluasi solusi }\end{array}$ \\
\hline $\begin{array}{l}\text { Anda membagi masalah kepada } \\
\text { bawahan terkait, mendapatkan ide dan } \\
\text { sarannya. Kemudian anda membuat } \\
\text { keputusan. Keputusan boleh atau tidak } \\
\text { boleh mencerminkan pengaruh anda di } \\
\text { bawahan. }\end{array}$ & $\begin{array}{l}\text { Anda berbagi masalah dengan bawahan } \\
\text { relevan secara individu, dapatkan ide } \\
\text { dan sarannya tanpa membawa mereka } \\
\text { sebagai kelompok. kemudian anda } \\
\text { membuat keputusan. Peranan di } \\
\text { mainkan bawahan anda secara jelas } \\
\text { menyediakan informasi yang and pinta, } \\
\text { kemudian mengevaluasi solusi. }\end{array}$ \\
\hline $\begin{array}{l}\text { Anda membagi masalah kemudian salah } \\
\text { satu bawahan anda bersama } \\
\text { menganalisis masalah dan memilih } \\
\text { solusi. Anda berkonstribusi untuk } \\
\text { menyelesaikan masalah dengan } \\
\text { konstribusi relkatif disetiap pengetahuan } \\
\text { daripada otoritas }\end{array}$ & $\begin{array}{l}\text { Anda membagi masalah dengan } \\
\text { bawahan yang relevan secara individu, } \\
\text { dapatkan ide dan saran mereka tanpa } \\
\text { membawa mereka sebagai bagian } \\
\text { kelompok. Kemudian anda } \\
\text { memutuskan. Keputusan ini mungkin } \\
\text { atau tidak mungkin mencerminkan }\end{array}$ \\
\hline $\begin{array}{l}\text { Anda mewakilkan masalah pada } \\
\text { bawahan anda, menyediakan informasi } \\
\text { yang relevan yang anda miliki, namun } \\
\text { berikan dia tanggung jawab. }\end{array}$ & $\begin{array}{l}\text { Anda membagi masalah dengan } \\
\text { bawahan sebagai kelompok. Bersama- } \\
\text { sama anda mengevaluasi alternatif dan } \\
\text { berusaha untuk mencapai kesepakan } \\
\text { sebagai solusi. Peran anda nampak } \\
\text { sebagai pimpinan koordinasi diskusi, } \\
\text { fokus pada masalah, dan meyakinkan } \\
\text { isu kritis yang dibahas. Anda tidak } \\
\text { berusaha untuk mempengaarugi } \\
\text { kelompok untuk mengadaptasi solusi } \\
\text { anda dan berkeinginan untuk menerima } \\
\text { dan menjalankan setiap solusi yang } \\
\text { mendukung masuk kelompok. }\end{array}$ \\
\hline
\end{tabular}

\section{KESIMPULAN}

Secara umum pembuatan keputusan (decision making) menggambarkan proses melalui bagaimana serangkaian kegiatan dipilih sebagai penyelesaian suatu masalah tertentu. Pengambilan keputusan merupakan hal yang sangat penting bagi individu maupun organisasi.

Terdapat tiga aspek dalam pengambilan keputusan (Janis \& Mann, 1977), yaitu :Pertama, kemampuan mempertimbangkan beberapa pilihan, Individu tidak hanya memikirkan manfaat terbesar yang akan didapatkan, tetapi juga berbagai macam pertimbangan dari pilihan yang dipilih maupun yang tidak dipilih. Kedua, kemampuan menghadapi tntangaan untuk mencapai situasi yang diinginkan. Berbagai tantangan yang kemungkinan akan dihadapi oleh individu dapat dilalui dengan baik. 
Ability : Journal of Education and Social Analysis

Volume 2, Issue 3, Juli 2021

Page : 83-92

Berkenaan dengan ketidakpastian, sehingga pilihan yang telah dipilih tidak dapat diubah lagi. Ketiga, kemampuan untuk menerima resiko yang ada.

Ada beberapa faktor yang mempengaruhi, antara lain: 1) Posisi kedudukan . 2) Masalah. 3) Situasi ., 4) Kondisi dan 5) Tujuan.

Proses pembuatan keputusan seorang manajer yaitu: 1) Pemahaman dan perumusan masalah, 2) Pengumpulan dan analisa data yang relevan. 3) Pengembangan alternatif-alternatif. 4) Evaluasi alternatif-alternatif. 5) Pemilihan alternatif terbaik. 6) Implementasi keputusan, 7) Evaluasi hasil-hasil keputusan.

Proses pengambilan keputusan memiliki berapa tahapan : Tahap 1 . Pemahaman dan Pemecahan Masalah. Tahap 2 Pengumpulan dan Analisis Data yang akurat. Tahap 3 Pegembangan Alternatif-Alternatif. Tahap 4 Evaluasi AlternatifAlternatif. Tahap 5 Pemilihan Alternatif Terbaik. Tahap 6 Implementasi Keputusan . Tahap 7 Evaluasi Hasil-Hasil. Keputusan.

Analisis SWOT adalah indentifikasi secara sistematis untuk merumuskan strategi perusahaan, termasuk strategi pemasaran. Analisis ini didasarkan logika yang dapat memaksimalkan Strengths (Kekuatan), Opportunities (Peluang), Weaknesses (Kelemahan), dan Treats (Ancaman). Proses pengambilan keputusan strategis selalu berkaitan dengan pengembangan misi, tujuan, strategi, dan kebijakan organisasi.

Tim pemecahan masalah dan pengambilan keputusan merupakan jantung kegiatan keputusan. Tempat pengendali internal merupakan persepsi orang -orang mengenai kemapuan mereka untuk melakukan tindakan khusus, seperti memecahkan masalah. Penggunaan metode pemecahan masalah yang efektif cenderung dapat menjamin bahwa akar permasalahan sudah diidentifikasi, ditentukan, dianalisis, dan diukur. Dengan menggunakan masukan ganda dan metode pemecahan masalah yang menjamun penemuan akar permasalahan, tim bisa menjajaki permasalahan kenbali menuju ke sebab awal masalah itu. Dengan mengidentifikasi akar permasalahan, dapat menggalakkan penyeleksian solusi yang berhadapan langsung dengan pemecahan daripada gejala-gejala saja.

\section{DAFTAR PUSTAKA}

Alawiyyah, sayyid, Dr., Membuat Keputusan Manajerial dalam Berbagai Organisasi Manajemen, al hay'ah al mishriyyah al'ammah li al kuttab, Kairo, 1987.

Al Ghadhban, Munir, Metode Edukatif pada Sirah Nabawiah, Pendidikan Kepemiminan.

Anonim,2011.Pengambilan Keputusan dalam Manajemen (Online), http://rizwarassundawi.blogspot.com/2011/05/makalah-pengambilan

keputusan-dalam.html (diakses tanggal 12 Mei 2021)

Covey, Stephen R. (1991). The 7 Habbits of Highly Effective People New York: A Fireside Book. 
Ability : Journal of Education and Social Analysis

Volume 2, Issue 3, Juli 2021

Page : 83-92

Duke, Daniel L., and Canady, Robert L. (1991). School Policy. New York: McGraw Hill, Inc.

Hargreaves, Andy., and Reynolds, David. (1989). Educational Politicies: Controversies and Qritiques. Wiltshere: The Falmer Press.

Hough, J.R. (1984). Educational Policy. New York: st.

Martin's Press. Kami, Michael J. (1988). Trigger Points. Singapore: McGraw Hill International Editions.

Rifai, Muhammad (2020) Pengambilan Keputusan . Jakarta : KENCANA

Water, Dan. (1991). 21st Century Management. Singapore: Prentice Hal 